\title{
Experimental and Numerical Study of an Earth-to-Air Heat Exchanger in Northeastern Poland
}

\author{
Aldona Skotnicka-Siepsiak ${ }^{1 *}$, Maciej Wesołowski², Janusz Piechocki \\ 'Institute of Building Engineering, Faculty of Geodesy, Geospatial and Civil Engineering, \\ University of Warmia and Mazury in Olsztyn, Michała Oczapowskiego 2, 10-719 Olsztyn, Poland \\ ${ }^{2}$ Department of Electrical, Power, Electronic and Control Engineering, Faculty of Technical Sciences, \\ University of Warmia and Mazury in Olsztyn, Michała Oczapowskiego 2, 10-719 Olsztyn, Poland
}

Received: 12 May 2017

Accepted: 11 July 2017

\begin{abstract}
Our paper presents empirical data from a laboratory experiment investigating the performance of an air-to-soil heat exchanger between July and August 2016. Measurements were performed in a laboratory of the Department of Civil Engineering and Building Engineering Physics of the University of Warmia and Mazury in Olsztyn. Empirical data were compared with the results of analytical calculations based on meteorological data for a typical meteorological year.
\end{abstract}

Keywords: air-to-soil heat exchanger, watt-hour efficiency

\section{Introduction}

In earth-to-air heat exchangers (EAHE), atmospheric air flows through a system of pipes buried in the ground, which acts as an energy buffer [1-2]. Throughout the year, soil temperature remains relatively constant below a certain depth (usually 2-3 m). The constant temperature is known as earth's undisturbed temperature, and it is lower than ambient temperature in summer and higher in winter. Undisturbed ground temperature in different geographical locations is determined by short-term weather variations, seasonal variations, soil moisture content, and thermal conductivity of soil [3].

In summer, EAHE systems cool the air that enters a ventilation unit [4]. Ground-coupled duct systems are

*e-mail: aldona.skotnicka-siepsiak@uwm.edu.pl researched extensively in countries with a subtropical climate, such as Brazil [5-6], a hot and arid climate [7], the hot and humid climate of Mexico in zones 2A and 3A [8], and in Italy [9], Turkey [10], and Egypt [11].

The performance of EAHE systems for pre-cooling air in mechanical ventilation systems in summer and pre-heating air in winter has been investigated in Central-Eastern Europe which is characterized by cold winters and hot summers [12]. Ground heat exchangers minimize energy use and supply ventilated premises with fresh, hygienic, and filtered air [13]. A review study by Tan and Love (2013) indicates that much of the literature focuses on cooling applications, systems with a smaller (approximately $300 \mathrm{~mm}$ ) diameter, and mild-to-hot climates. Research into EAHE systems for heating purposes in cold climates is less extensive, but its results are promising. According to numeric simulations performed for residential buildings in Norway [14] and 
Montreal in northern Canada [15-16], EAHE installations can increase the temperature of the supplied air by up to $12^{\circ} \mathrm{C}$ (from $-7^{\circ} \mathrm{C}$ to $+5^{\circ} \mathrm{C}$ ). Energy gains are even higher when the temperature of ambient air is very low [17]. In the temperate climate of Germany, empirical data acquired over a period of one year indicate that the temperature of air can increase by $16^{\circ} \mathrm{C}$ between the inlet and outlet of a ground heat exchanger [18]. In Warsaw, where the average annual temperature is $8.1^{\circ} \mathrm{C}$, the relevant increase in air temperature in winter approximated $15^{\circ} \mathrm{C}$ [19]. The results of the above studies indicate that EAHE systems are comparatively efficient in heating supply air in cold climates [20]. Researchers and designers have a growing interest in EAHE systems, which offer a promising solution for improving thermal comfort at low cost [21]. In studies evaluating the performance of EAHE systems, empirical data are compared with the results of numerical analyses [8]. Research methods and one-dimensional numerical models have been developed to analyze the performance of EAHE systems based on the energy conservation equation [22] [23]. Computer programs supporting multi-dimensional simulations of the thermal performance of EAHE are being developed [24]. Mathematical models are validated based on experimental results [25-26]. Numerical methods are used to evaluate and optimize the parameters of EAHE installations (pipe diameter, pipe material, pipe space, pipe length, and flowing fluid velocity) [27].

Earth-to-air heat exchangers can be further divided into open-loop and closed-loop systems. Open-loop installations are used in buildings with a high demand for fresh air, such as hospitals, industrial plants, and public utility buildings. In these systems, air is drawn from an outdoor inlet and supplied to the building via a pipe system. Closed-loop systems that recover heat from spent air can be used for ventilation in residential buildings. Closed-loop systems increase the energy efficiency of buildings [8, 28]. The performance of EAHE systems is analyzed in exergetic and economic assessments [2930]. Ozgener et al. (2011) found that in EAHE systems for greenhouse heating, exergy destruction results mainly from blower losses and heat exchange losses [31]. The efficiency of EAHE is also tested in specific locations because their thermal performance can be substantially overestimated when the dynamic interactions between a heat exchanger and the environment are neglected [24, 32-33].

A dedicated laboratory station was developed at the University of Warmia and Mazury in Olsztyn, Poland, to investigate the energy efficiency of EAHE. A measurement system was designed for analyzing changes in the temperature and volume of air passing through the EAHE. Measurement data were registered to determine the actual transfer of energy from the ground to the ventilation system for heating purposes in winter and for cooling purposes in summer. This paper analyzes the results of measurements conducted between 1 July and 30 September 2016 and compares them with the results of theoretical calculations based on the International Ground Source Heat Pump Association (IGSHPA) method [34]. (Data were not recorded between 6 and 11 July 2016 due to technical problems.)

\section{Laboratory Station}

The laboratory station comprised the AwaduktThermo system of ground-coupled pipes buried in the ground at a depth of $2.10 \mathrm{~m}$ (at the point of intersection with the building's cellar wall) to $2.28 \mathrm{~m}$ (rainwater tank). The pipes had a downward slope in the direction of the rainwater tank in the vicinity of the AwaduktThermo air inlet tower. The pipeline had a total length of $41 \mathrm{~m}$, with an external pipe diameter of $0.2 \mathrm{~m}$ and four $90^{\circ} \mathrm{C}$ elbows pipes.

The measuring system comprised resistance temperature detectors mounted on the external northern wall of the building and by the EAHE outlet supplying air to the ventilation unit. In the EAHE, the air flow rate was measured with a detector installed inside the pipeline by the inlet to the ventilation unit in the cellar. The measurements were registered by a Siemens controller in real time and were averaged in hourly intervals.

\section{Analyzing Measured Data}

We used a database of hourly air temperature and air flow rate measurements conducted between 1 July and 30 September 2016. The heat gain from the EAHE was determined on an hourly basis during the analyzed period with the use of the following formula [35]:

$$
Q_{w}=\frac{\dot{m} \cdot c_{p} \cdot\left(T_{w}-T_{e}\right) \cdot z}{3,6} \quad \mathrm{Wh}
$$

...where:

$Q_{w}$ - heat gain from the EAHE (Wh)

$\dot{m}$ - the mass flow rate of air $(\mathrm{kg} / \mathrm{s})$

$c_{p}$ - specific heat of air determined based on the formula $\mathrm{kJ} /(\mathrm{kg} \cdot \mathrm{K})$

$T_{w}$ - air temperature measured at the EAHE outlet $\left({ }^{\circ} \mathrm{C}\right)$

$T_{e}^{w}$ - air temperature measured at the air inlet $\left({ }^{\circ} \mathrm{C}\right)$

$z$ - averaging interval (1 hour)

\section{Theoretical Calculations for a Typical Meteorological Year}

Theoretical heat gain from the EAHE was calculated with the IGSHPA method, which is used to select groundcoupled heat exchangers for heat pump systems [34]. Heat gain in every hourly interval of the analyzed period was determined with the use of the IGSHPA method based on average hourly temperatures of ambient air $T_{e}$ in a typical meteorological year (according to mr.gov.pl). The method of determining the above values was described by Nawarowski [36]. The average hourly temperatures of air at the EAHE outlet $T_{w}$ were determined based on 


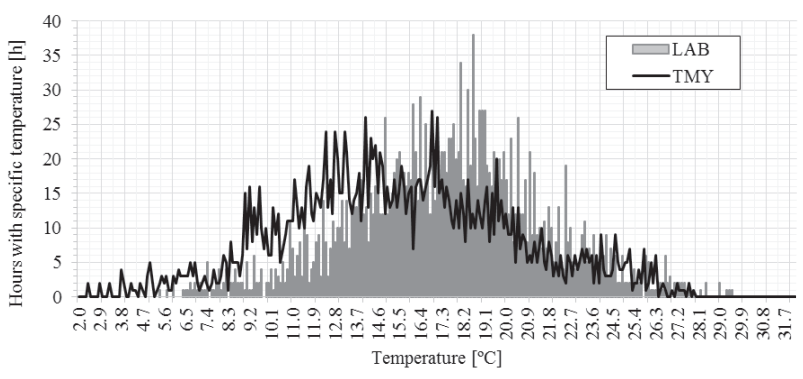

Fig. 1. Distribution of air temperatures between July and September 2016 in Olsztyn based on the performed measurements and a meteorological database (TMY). (Source: own elaboration)

the IGSHPA method [34]. The measured parameters were used in calculations according to the method described by Biernacka [37-38].

\section{Results and Discussion}

\section{Weather Conditions}

The frequency distribution of average hourly temperatures of ambient air measured between 1 June and 30 September 2016 and calculated based on data for a typical meteorological year [39] is presented in Fig. 1. A comparison of the data in Fig. 1 indicates that ambient temperatures in the evaluated period differed from a typical meteorological year. The lowest recorded temperature of $5.4^{\circ} \mathrm{C}$ occurred for only one hour, whereas in a typical meteorological year the lowest temperature $\left(5.4^{\circ} \mathrm{C}\right)$ lasted two hours. In a typical meteorological year, the lowest temperature was $2.4^{\circ} \mathrm{C}$, and it lasted for two hours, whereas temperatures below $5.4^{\circ} \mathrm{C}$ were recorded over a period of 30 hours. The average temperature of ambient air measured between July and September 2016 was $17.5^{\circ} \mathrm{C}$, whereas the average temperature in a typical meteorological year was $15.5^{\circ} \mathrm{C}-2.0^{\circ} \mathrm{C}$ lower than the measured temperature. The highest air temperature in the evaluated period was $29.5^{\circ} \mathrm{C}$ and it occurred for one hour, whereas the highest temperature in a typical meteorological year was $27.9^{\circ} \mathrm{C}$, which lasted one hour and was $1.6^{\circ} \mathrm{C}$ lower than the measured temperature. In the experiment, temperatures higher than $29.5^{\circ} \mathrm{C}$ occurred for three hours. The most frequently registered ( 38 hours) temperature in the evaluated period was $18.6^{\circ} \mathrm{C}$, whereas the most frequent ( 27 hours) temperature in a typical meteorological year was $16.9^{\circ} \mathrm{C}$.

\section{Amount of Heat Transferred by the Ground Exchanger to Flowing Air}

Daily heat gains from a ground exchanger calculated based on laboratory measurements and a database for a typical meteorological year are presented in Fig. 2 and Table 1. Heat gain was determined at $182.07 \mathrm{kWh}$ based on the measurements conducted between July and September 2016, and it was calculated at $197.49 \mathrm{kWh}(15.42 \mathrm{kWh}$ higher) based on the database for a typical meteorological year. Cooling load was determined at $-12.22 \mathrm{kWh}$ in the analyzed period and at $-225.82 \mathrm{kWh}(213.60 \mathrm{kWh}$ higher) based on data for a typical meteorological year. The average daily heat gain determined in the experiment during the analyzed period was $1.63 \mathrm{kWh}$ with maximum heat gain of $4.69 \mathrm{kWh}$ and maximum cooling load of $-2.52 \mathrm{kWh}$. The calculations based on data for a typical meteorological year revealed average daily heat gain of $-0.33 \mathrm{kWh}$ (cooling), with maximum heat gain of $10.34 \mathrm{kWh}$ and maximum cooling load of $-11.99 \mathrm{kWh}$. Monthly heating and cooling loads in the analyzed period are presented in Table 1.

Distribution of Air Temperatures Measured at the Air Inlet and the EAHE Outlet and Calculated with the use of the IGSHPA Method

The distribution of air temperatures measured at the air inlet and the EAHE outlet and calculated based on the database for a typical meteorological year is presented in Fig. 3. A comparison of temperatures measured at the EAHE outlet and the air inlet indicates that fluctuations in ambient temperature induced changes in the temperature measured at the EAHE outlet and the air inlet, although the corresponding changes were less extensive due to the thermal behavior of soil. The minimum temperature at the EAHE outlet was $9.3^{\circ} \mathrm{C}$, and the maximum temperature was $27.1^{\circ} \mathrm{C}$. The difference in air temperature between the EAHE outlet and the air inlet ranged from $-2.4^{\circ} \mathrm{C}$ (cooling) to $4.4^{\circ} \mathrm{C}$ (heating). The smallest difference was observed when the temperature at the air inlet suddenly increased by $9.9^{\circ} \mathrm{C}$ (from $19.6^{\circ} \mathrm{C}$ to $29.5^{\circ} \mathrm{C}$ ) on 2 July between 5 a.m. and 5 p.m., and when the temperature at the EAHE outlet

Table 1. Monthly heating and cooling loads between July and September 2016.

\begin{tabular}{|c|c|c|c|c|}
\hline & \multicolumn{2}{|c|}{ Laboratory measurements } & \multicolumn{2}{c|}{ Theoretical calculations for a typical meteorological year } \\
\hline & Cooling load $(\mathrm{kWh})$ & Heat gain $(\mathrm{kWh})$ & Cooling load $(\mathrm{kWh})$ & Heat gain $(\mathrm{kWh})$ \\
\hline July 2016 & -6.42 & 37.24 & -57.58 & 44.00 \\
\hline August 2016 & -4.45 & 62.42 & -79.92 & 58.27 \\
\hline September 2016 & -1.35 & 82.41 & -88.32 & 95.22 \\
\hline
\end{tabular}

(Source: own elaboration) 


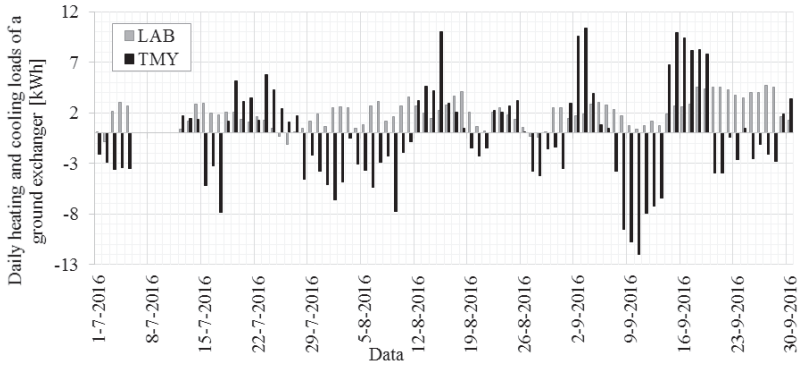

Fig. 2. Daily distribution of heating and cooling loads from a ground heat exchanger between July and September 2016 measured in the laboratory of the Department of Civil Engineering and Building Engineering Physics of the University of Warmia and Mazury in Olsztyn (source: own elaboration).

increased by $7.1^{\circ} \mathrm{C}$ in the corresponding period (from $19.9^{\circ} \mathrm{C}$ to $27.1^{\circ} \mathrm{C}$ ). The greatest difference in temperature was noted during the steepest decrease in ambient temperature of $8.9^{\circ} \mathrm{C}$ (from $18.9^{\circ} \mathrm{C}$ to $10.0^{\circ} \mathrm{C}$ ) between 3 p.m. on 17 September and 7 a.m. on 18 September. During that period, the temperature at the EAHE outlet decreased by only $5.1^{\circ} \mathrm{C}$ (from $19.5^{\circ} \mathrm{C}$ to $14.4^{\circ} \mathrm{C}$ ).

The distribution of temperatures at the EAHE outlet for a typical meteorological year revealed lower temperatures than the measured data. The fluctuations in ambient temperature during a typical meteorological year were similar to those noted within the measured range. In the calculations, the temperature difference between the air inlet and the EAHE outlet ranged from $-10.3^{\circ} \mathrm{C}$ to $11.0^{\circ} \mathrm{C}$. The lower limit was approximately 4.3 -fold higher than the measured values, whereas the upper limit was approximately 2.5 -fold higher than the measured values.

The noted differences can be partially attributed to variations in the analyzed data. In the experiment, the minimum temperature of $5.4^{\circ} \mathrm{C}$ was determined at 07:00 on 27 September. The temperature at the EAHE outlet reached $9.3^{\circ} \mathrm{C}$ during the above measurement. Based on data for a typical meteorological year, the corresponding temperature was $10.8^{\circ} \mathrm{C}$, and the temperature at the EAHE outlet reached $11.4^{\circ} \mathrm{C}$. The differences in the temperature of ambient air were not extensive enough to

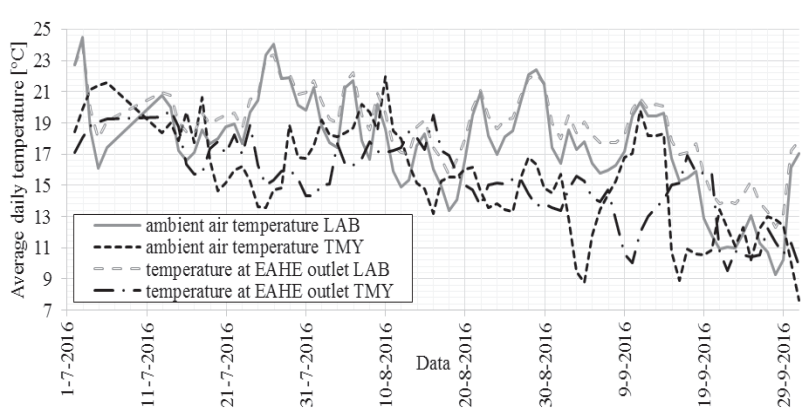

Fig. 3. Distribution of average daily temperature measured at the air inlet and the EAHE outlet (LAB) and calculated based on data for a typical meteorological year (TMY) (source: own elaboration).

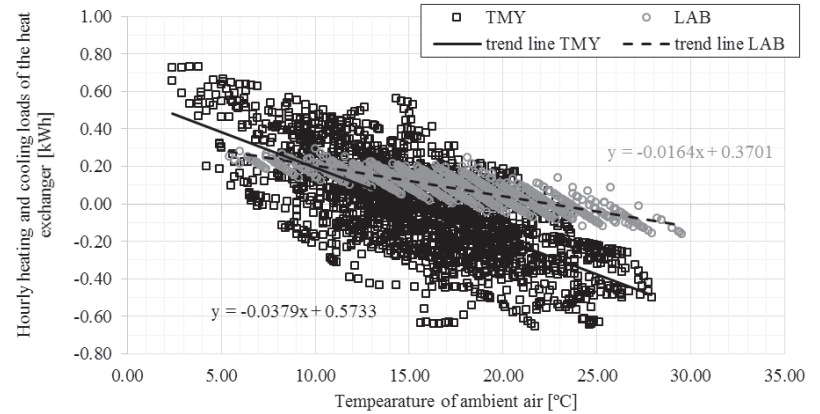

Fig. 4. Hourly heating and cooling loads measured in the experiment (LAB) and calculated based on mean hourly data for a typical meteorological year (TMY) (source: own elaboration).

justify such considerable variations in temperature at the EAHE outlet.

Heat gains measured in the experiment and calculated with the use of the IGSHPA method based on data for a typical meteorological year.

In Fig. 4, the trend lines representing hourly heat gains measured in the experiment and calculated based on mean hourly data for a typical meteorological year are similar, although laboratory results deviate toward higher average values of hourly temperatures. The maximum hourly heat gain was determined at $0.29 \mathrm{kWh}$ in the experiment and at $0.73 \mathrm{kWh}$ in theoretical calculations. The maximum hourly cooling load was determined at $-0.16 \mathrm{kWh}$ based on measured data and at $-0.65 \mathrm{kWh}$ based on data for a typical meteorological year. The average heat gain was $0.08 \mathrm{kWh}$ in the experiment and the average cooling load was $-0.01 \mathrm{kWh}$ for a typical meteorological year.

An analysis of trend lines in Fig. 5 indicates the greatest discrepancy between heat gains relative to air temperature at the EAHE outlet. Laboratory measurements with a near-horizontal line and significant scatter of measurement points demonstrate weak correlations between heat gains with a decreasing trend in the direction of higher air temperature at the EAHE outlet. The highest hourly heat gain $(0.29 \mathrm{kWh})$ was determined when air temperature at the EAHE outlet reached $14.4^{\circ} \mathrm{C}$, whereas the highest hourly cooling load

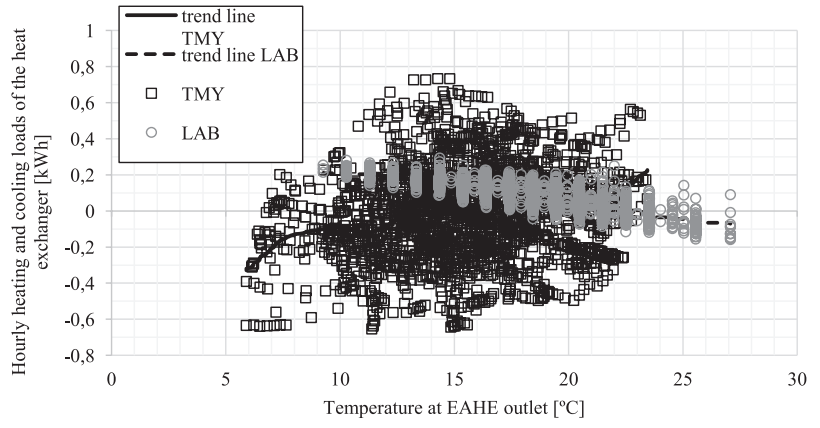

Fig. 5. Heating and cooling loads from the ground heat exchanger based on data for a typical meteorological year (TMY) and the values measured in the experiment (LAB) relative to air temperature at the EAHE outlet (source: own elaboration). 


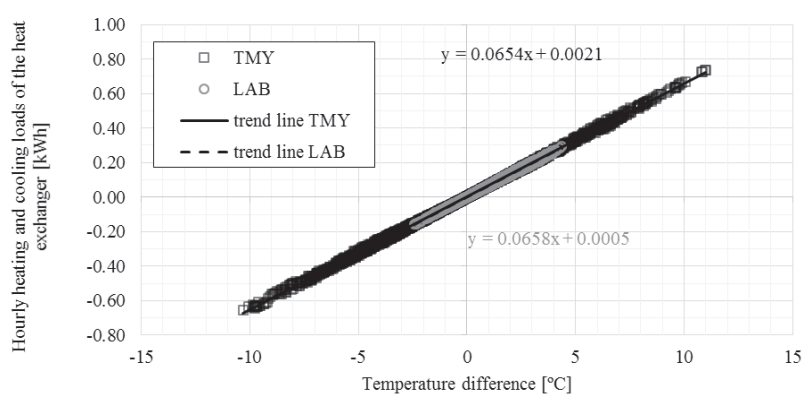

Fig. 6. Heating and cooling loads from a ground heat exchanger based on data for a typical meteorological year (TMY) and the values measured in the experiment (LAB) relative to differences in air temperature between the EAHE outlet and the air inlet (LAB) (source: own elaboration).

$(-0.16 \mathrm{kWh})$ was observed for the highest temperature at the EAHE outlet of $27.1^{\circ} \mathrm{C}$.

The curves in Fig. 5 were fitted with the application of GMDH Shell software, a professional neural network software that solves time series predicting and data mining tasks by building artificial neural networks and applying them to the input information [40].

In the results calculated based on data for a typical meteorological year, the trend line slopes downward in the direction of lower air temperature at the EAHE outlet. The highest hourly cooling load $(-0.65 \mathrm{kWh})$ was noted when the temperature at the EAHE outlet reached $11.4^{\circ} \mathrm{C}$. The highest hourly heat gain $(0.73 \mathrm{kWh})$ was determined when the temperature at the EAHE outlet reached $14.8^{\circ} \mathrm{C}$.

Heating and cooling loads from the ground heat exchanger calculated based on data for a typical meteorological hear and data measured in the experiment based on the difference between air temperature at the EAHE outlet and the air inlet are presented in Fig. 6. Trend lines are similar, and data scatter relative to trend lines is not significant. The greatest differences were observed in the temperature at the EAHE outlet and ambient air temperature. The difference in measured data ranged from $-2.42^{\circ} \mathrm{C}$ (with the highest hourly cooling load of $-0.16 \mathrm{kWh}$ ) to $4.36^{\circ} \mathrm{C}$ (with the lowest hourly heat gain of $0.29 \mathrm{kWh}$ ). In the calculations based on data for a typical meteorological year, the smallest difference in temperature of $-10.31^{\circ} \mathrm{C}$ was similar to that noted in the experiment (with the highest hourly cooling load of $-0.65 \mathrm{kWh}$ ), whereas the greatest difference of $11.0^{\circ} \mathrm{C}$ significantly exceeded the measured results (with the highest hourly heat gain of $0.73 \mathrm{kWh}$ ).

\section{Conclusions}

1) The analyzed period (July-September 2016) was unusually warm in comparison with data for a typical meteorological year. The average temperature of ambient air measured in the experiment was $2.0^{\circ} \mathrm{C}$ higher than the 30-year average. The maximum measured temperature $\left(29.5^{\circ} \mathrm{C}\right)$ was $1.6^{\circ} \mathrm{C}$ higher than the maximum temperature in the corresponding period of a typical meteorological year. An analysis of temperature frequency distributions revealed that the measured temperatures in the range of $13-22^{\circ} \mathrm{C}$ and the calculated temperatures in the range of $9-20^{\circ} \mathrm{C}$ occurred for more than 10 hours. The most frequently measured temperatures were around $3^{\circ} \mathrm{C}$ higher than the temperatures characteristic of a typical meteorological year. The most common measured temperature ( 38 hours) was $18.6^{\circ} \mathrm{C}$, whereas the most frequent temperature ( 27 hours) in a typical meteorological year was $1.7^{\circ} \mathrm{C}$ lower.

2) A comparison of mean daily heating and cooling loads from the EAHE points to average daily heat gain of $1.63 \mathrm{kWh}$ with maximum heat gain of $4.69 \mathrm{kWh}$ and maximum cooling load of $-2.52 \mathrm{kWh}$. The calculations based on the IGSHPA method produced an average daily cooling load of $-0.33 \mathrm{kWh}$, with maximum heat gain of $10.34 \mathrm{kWh}$ and maximum cooling load of $-11.99 \mathrm{kWh}$. The total heat gain from the EAHE was only $8 \%$ lower than that determined in theoretical calculations. The greatest differences were observed in cooling loads. In the experiment, cooling load was determined at $-12.22 \mathrm{kWh}$, and it accounted for only $5.4 \%$ of the cooling load calculated with the use of the IGSHPA method. The very low cooling load in the experiment could be attributed to roundthe-clock operation of fans in spring, which increased ground temperature.

\section{References}

1. SANTAMOURIS M., PAVLOU K., SYNNEFA A., NIACHOU K., KOLOKOTSA D., Recent progress on passive cooling techniques, Energy Build. 39, 859, 2007.

2. HOLLMULLER P., LACHAL B., Cooling and preheating with buried pipe systems: monitoring, simulation and economic aspects, Energy Build, 5, 509, 2001.

3. OZGENER O., OZGENER L., TESTER J.W. A practical approach to predict soil temperature variations for geothermal (ground) heat exchangers applications. International Journal of Heat and Mass Transfer 62, 473, 2013.

4. KHABBAZ M., BENHAMOU B., LIMAM K., HOLLMULLER P., HAMDI H., BENNOUNA A. Experimental and numerical study of an earth-to-air heat exchanger for air cooling in a residential building in hot semi-arid climate. Energy and Buildings 125, 109, 2016.

5. VAZ J., SATTLER M.A., DA R., BRUM S., DOS SANTOS E.D., ISOLDI L.A., An experimental study on the use of earth-air heat exchangers (EAHE), Energy Build. 72, 122, 2014.

6. VAZ J., SATTLER M.A., DA R., BRUM S., DOS SANTOS E.D., ISOLDI L.A., Experimental and numerical analysis of an earth-heat exchanger, Energy Build. 43, 2476, 2011.

7. BANSAL V., MISHRA R., DAS AGARWAL G., MATHUR J., Performance analysis of integrated earth-air tunnelevaporative cooling system in hot and dry climate, Energy. Build. 47, 525, 2011. 
8. DO S.L., BALTAZAR J.C., HABERL J. Potential cooling savings from a ground-coupled return-air duct system for residential buildings in hot and humid climates. Energy and Buildings 103, 205, 2015.

9. ASCIONE F., BELLIA L., MINICHIELLO F., Earth-to-air heat exchangers for Italian climates, Renew. Energy 36 (8), $2177,2011$.

10. OZGENER L. A revive on the experimental and analytical analysis of earth to air heat exchanger (EAHE) systems in Turkey. Renewable and Sustainable Energy Reviews. 15 (9) 4483, 2011.

11. SERAGELDIN A.A., ABDELRAHMAN A.K., OOKAWARA S., Eart-Air Heat Exchanger thermal performance in Egypian conditions: Experimental results, mathematical model, and Computational Fluid Dynamics simulation. Energy Conversion and Management 122, 25, 2016.

12. HOLLMULLER P., LACHAL B., Air-soil heat exchangers for heating and cooling of buildings: design guidelines, potentials and constraints, system integration and global energy balance, Appl. Energy 119, 476, 2014.

13. KOCZOROWSKI J., Energooszczędne ogrzewanie i chłodzenie hal z GPWC. Chłodnictwo i Klimatyzacja 10, 44, 2014.

14. WACHENFELDT B.J. Natural Ventilation in Buildings Detailed Prediction of Energy Performance. Ph.D. Thesis, Norwegian University od Science and Technology, Trondheim, Norway (Google Scholar) 2003.

15. JEONG Y. Modeling of a Hybrid - Ventilated Building: Grong School". Master's Thesis, Concordia University, Montreal, Canada 2002 http://spectrum.library.concordia. $\mathrm{ca} / 1790 /$

16. ZHANG J., HAGHIGHAT F. Simulation of Earth-toAir Heat Exchangers in Hybrid Ventilation Systems. In Proceedings of 9th International Building Performance Simulation Association Conference, Montreal, Canada, 11, 2003.

17. BAXTER D.O. Energy exchangers and related temperatures of an earth-tube heat exchanger in the heating mode. Trans. ASAE 35, 275, 1992.

18. PFAFFEROTT J. Evaluation of earth-to-air heat exchangers with a standardized method to calculate energy efficiency. Energy build. 35, 971, 2003.

19. TRZASKI A., ZAWADA B. The influence of enviromental and geometrical factors on air-ground tube heat exchanger energy efficiency. Build Eviron. 46, 14364, 2011.

20. TAN L., LOVE J.A., A Literature Review on Heating of Ventilation Air with Large Diameter Earth Tubes in Cold Climates. Energies 6 (8) 3734, 2013.

21. XAMAN J., HERMANDEZ-LOPEZ I., ALVARADOJUAREZ R., HERNANDEZ-PEREZ I., ALVAREZ G., CHAVEZ Y. Pseudo transient numerical study of an earthto-air heat exchanger for different climates of Maxico. Energy and Buildings 99, 273, 2015.

22. NIU F., YU Y., YU D., LI H., Heat and mass transfer performance analysis and cooling capacity prediction of earth to air heat exchanger. Appl. Energy 137, 211, 2015.

23. BANSAL V., MATHUR J., Performance enhancement of earth air tunnel heat exchanger using evaporative cooling. Int. J. Low Carbon Technol. 4, 150, 2009.

24. GAN G., Dynamic thermal simulation of horizontal ground heat exchangers for renewable heating and ventilation of buildings. Renewable Energy 103, 361, 2017.
25. VAZ J., SATTLER M.A, BRUM R.D.S, DOS SANTOS E.D., ISOLDI L.A., An experimental study on the use of Earth-Air Heat Exchangers (EAHE). Energy and Building 72, 122, 2014.

26. AHMED S.F., AMANULLAH M.T.O., KHAN M.M.K., RASUL M.G., HASSAN N.M.S., Parametric study on thermal performance of horizontal earth pipe cooling system in summer. Energy Conversion and Management 114, 324, 2016.

27. HATRAF N., CHABANE F., BRIMA A., MOUMMI N., MOUMMI A. Parametric study of to design an earth to air heat exchanger with experimental validation Eng J. 18, 41, 2014.

28. BISONIYA T.S., KUMAR A., BEREDAR P. Study on calculation models of earth-air heat exchanger systems, J. Energy 15, 2014.

29. OZGENER O., OZGENER L. Exergoeconomic analysis of an underground air tunnel system for greenhouse cooling system. Int. J.Refrig 33 (5) 995, 2010.

30. OZGENER O., OZGENER L. Experimental study of the exergetic performance of an underground air tunnel system for greenhouse cooling. Renewable Energy 35 (12) 2804, 2010.

31. OZGENER O., OZGENER L. Determining the optimal design of a closed loop earth to air heat exchanger for greenhouse heating by using exergoeconomics. Energy and Buidlings 43, 960, 2011.

32. MIHALAKAKOU G., LEVIS J.O., SANTAMOURIS M. The influence of different ground Covers on the heating potential of earth-to-air heat exchangers, Renew. Energy 7 33, 1996.

33. GONDALEZ R.G., VERHOEF A., VIDALE P.L., MAIN B., GAN.G. WU Y. Interactions between the physical soil environment and a horizontal ground coupled heat pump for a domestic site in the UK, Renew. Energy 44, 141, 2012.

34. BOSE J.E., PARKER J.D., MCQUISTON F.C. Design/data manual for closed-loop ground-coupled heat pump systems, ASHRAE, Atlanta. 1985.

35. BISONIYA T.S. Design of earth-air heat exchanger system. Geothermal Energy, 3.1, 18, 2015.

36. NAROWSKI P. Methods of determination of typical meteorological years TMY2, WYEC2 and according to the standard EN ISO 15927-4, Ciepłownictwo Ogrzewnictwo Wentylacja (Heat Engineering Heating Ventilation) nr $\mathbf{1 2}$ (45) 2014 [In Polish].

37. BIERNACKA B. Semi-empirical equation describing the natural temperature field in the area of Bialystok, Budownictwo i Inżynieria Środowiska (Civil Engineering and Environmental Engineering 1, 5, 2010 [In Polish].

38. POPIEL C.O., WOJTKOWIAK J., BIERNACKA B. Measurement of temperature distribution in ground" Experimental Thermal and Fluid Science 25, 301, 2001.

39. Ministerstwo Rozwoju. Available online: https://www. mr.gov.pl/strony/zadania/budownictwo/dane-doswiadectwo-charakterystyki-energetycznej-budynkow/ (accessed on 11.02.2017).

40. GMDH Software Available online: https://gmdhsoftware. com/neural-network-software (accessed on 19.06.2017) 